\title{
Author-Publisher Relationship in the Digital Era: Disintermediation and Proliferation of Self-Publishing
}

\author{
PK Madhavan, K Sundar
}

\begin{abstract}
In the wake of disintermediation and proliferation of self-publishing, this study, the first of its kind in India, has research questions to author respondents on their inclination towards self-publishing and their perceptions on author-publisher relationships in the digital era. The study also asks questions pertaining to the perceived drawbacks of traditional publishing that is of time taken by publishers to publish a book, the endless wait of authors for a publishing decision, the ease or difficulty in finding a publisher especially for first time authors and their comfort factor with publishers in terms of royalty and direct interaction sans agents.
\end{abstract}

Keywords: Disintermediation Self-publishing, Print on Demand, Digital Publishing, Digital DisruptionAuthors , Traditional Publishing , Curation

\section{INTRODUCTION}

The structural position of the publisher in the entire publishing process is that of an intermediary-one who connects authors with target readers.

Traditional publishers play many roles. Giles Clark and Angus Philips(2014) in describing what publishers do mention the various roles played by publishers including that of investment, marketing, value-additions to content, content selection and curation, motivating authors at various stages of the publishing project as also the role of protecting copyright. They say that," "publishers are not mere printers or middlemen but add value to an authors' work ... develop an author's career, and make a market for their works ... commission authors before manuscripts are written and confer the authority of their brand on an author's work".

In the digital age, authors can upload content, self-publish, or use the services of self-publishers and be in direct touch with readers. The digital age is one of proliferation and abundance. Traditional publishing is one of finite resources and gatekeeping (Clark and Philips 2014). Print on demand technology and self-publishing has radically transformed theway authors view the domain of publishing. For publishers, the digital environment has led to several stakeholders in the domain and disintermediation thereby upsetting and disrupting carefully honed ways of doing business.

As Michael Bhaskar (2014) says, we are in the age of disintermediation. Disintermediation affects every link in the supply chain including authors, agents, aggregators,

Revised Manuscript Received on October 15, 2019.

PK Madhavan: Department of Management Studies, SCSVMV University,Kancheepuram, Tamil Nadu, India

K Sundar: Department of Commerce, Annamalai University, Chidambaram, Tamil Nadu, India. publishers, printers, wholesalers, retailers, librarians and so on. (Clark and Philips 2013). Print on demand technology has enabled publishers in certain genres to reduce costs and solve inventory and warehousing problems. Authors pay for publishing services and retain control over their works not wanting to wait endlessly for publisher acceptance or rejection. Successful authors like JK Rowling straddle the traditional and digital publishing models with success. The Pottermore website and e-books are controlled by the author while the print version remains with the print publisher. Agents became publishers or provide services to authors disintermediating publishers. Publishers attempt to attract customers directly disintermediating channel members like wholesalers and retailers. Librarians became university publishers. Large retailers use their customer-base and knowledge of customer tastes to attract authors and turn publishers.Michael Bhaskar (2013) talks of retailers and technology players in the book space, authors and literary agents taking on the role of publishers and new players as potent competitors to traditional publishers.

Traditional publishing relies on gatekeeping and selection of content. In contrast, Wikipedia has shown the way with user contribution, user and expert reviews and improvements by readers as a sustainable model. The writers in the traditional system had to wait for long to get published. First time authors found it difficult to get published. It is against this background that self-publishing became a viable option for many writers.

Rasana Atreya (2012) sold many copies of her ebook 'Tell a Thousand Lies'on Amazon Kindle and was later offered a publishing contract for a paperback print version of her e-book by a traditional publisher. She declined as the publisher wanted electronic rights (in addition to print rights) which she was unwilling to let go. Many authors first self-publish print or electronic versions and then sign up with interested traditional publishers-they find this route easier than submitting their scripts to agents or editors and waiting long periods of time to get an answer.Savi Sharma's Everyone has a story was first self-published and sold about 5000 copies on Amazon. In June 2016, she signed a book deal with Westland. (Hindu, July5, 2016).

Digital publishing has embraced the concept of artist as entrepreneur and control in the hands of the individual author. Self-publishing always existed but success stories like Stephen King's Riding the Bullet, a mass consumption e-book that was downloaded half a million times in the year 2000 opened the floodgates of self-publishing. EL James's 
Fifty Shades of Grey sold 60 million copies on Amazon, had e-book and print on demand paperback and was later licensed to Vintage Books. Likewise, Blood, Sweat and Tea by Tom Reynolds was first offered free online and as an e-book.

It sold 300000 copies in print. (FICCI Report)

In its purest form, self-publishing is when the author handles all aspects of publishing including financing, editorial and typesetting, production, marketing and logistics. (Nitin Shah 2017). As the name signifies, self-publishing is when an author decides that his/her content is publish-worthy and does not depend on external agencies like agents, editors, and publishers to accept the script for publication. Authors finance the production, use social media, their own network, and online channels to market and sell the book. However, all authors are not well-equipped to handle all aspects of the publishing process. Self-publishing authors in such cases approach firms who provide publishing services sometimes specific services such as editorial, typesetting, print on demand, printing, ISBN, cover design and so on. Some publishing solutions companies help in content discoverability, social media presence, online channel routes, and other technology related aspects of publishing.

Naveen Valsakumar (2017) of Notion Press says that, "self-publishing is all about the author... the author has complete control ... and is the CEO of the operation". This echoes with what Ogorek (2017) writes as shift in power and control of the market with the author. He also feels that big publishers will publish projects that require big budgets and resources. The trend of traditionally large or mid-size companies scouting and picking up self-published books and the movie industry showing interest in self-published authors augurs well for the self-publishing authors. However, for publishers though it is a clear sign of and declining influence and market share. As Michael Bhaskar (2013) points out, "Disintermediation isn't an abstract or trivial possibility. It is a live threat to publishers of all kinds". However, Joseph Esposito (2017) says books are multifarious. He adds that, it is a mistake to make a book more like a web like publication as some ideas require space to stretch out and, in some areas, extended synthesis... the future of the book is in making it more like itself.

\section{LITERATURE REVIEW}

Matias Vaara (2010) in his study of 'Digital Disruption of the Book Publishing Industry' in Finland traces the trigger points that make digital publishing attractive and, in the process, rendering publishers increasingly redundant or less influential and insignificant. He presents a theoretical framework of innovation and correlates it with the inability of analogue publishing to tap the non-consuming reader. He opines that digital publishing does exactly that of being able to bring more players, both amateurs and professionals in a participatory, and interactive mode. In digital publishing, writers and readers interact and become co-creators of content and Vaara says that the power shifts to peer groups and to reader communities and the nature of the medium is customer-centric and community or social-oriented. The hard problems according to him are in mass amateurisation and getting found in the sea of information. However, authors relish their new-found freedom, of not having to wait endlessly for a publishing decision and being in control of their creation.

Cantatore (2011) welcomes the technological innovations in publishing especially the options available to authors to self-publish their works. In her interviews with authors in Australia, she discerns a sense of euphoria amongst authors to be in control of their works, publish e-books online and use print on demand technology to print books according to demand. But authors, she feels, are equally concerned about the marketing aspects for their works when they self-publish. She writes that all authors are not adequately skilled to self-publish as the whole process is new, but quotes Eltham (2009) that serious authors who want to make an impact understand that in order to make self-publishing successful, an author has to be an entrepreneur, a small business manager, a savvy marketer, a tireless communicator, and have a distribution system in place.

Kevin Smith (2012) says, "Everyone has a book inside them" and that self-publishing using digital technology of Print on Demand and Internet Platforms facilitate writers to become published authors. He explains that self-publishing enables authors to have direct control of the creation of their worksthat is without editorial interventions as also of retaining copyright and in marketing their creations. However, this according to Smith requires authors to expend valuable time and effort in developing sales channels, and networks, interact on social media, and adopt viral marketing techniques. He says authors like Amanda Hocking have been extremely successful with their self-publishing efforts that led to her signing a four-book deal with a traditional publisher. Kevin Smith says that self-publishers are looking to the music industry for guidance in remixes, and playlists, a new way of delivering customised information.

Frania Hall (2013) explains that the ease with which publishing, and distribution can happen over the internet as significant impacts on the publishing environment. She avers that content is no longer scarce and text and images are aplenty on social media sites whether they are amateur, bad or unregulated, publishing has become democratised and content is publishable by anyone. She points out that the big technology players Google, Amazon and Apple are foraying into the content marketplace albeit with different motives. She highlights the impact of the Amazon platform and the kindle reader as having benefitted authors who want to self-publish especially as Amazon provides the marketing reach and allows authors to retain the major earnings from sales deducting a percentage from the proceeds while allowing authors to retain copyright. She also mentions other platforms which track sales and manage sales relationships and manage bibliographic details.

Michael Bhaskar (2013) is emphatic that digital publishing uproots the very foundation of traditional publishing as the structure of the internet enables publishing to be done by anyone. The fundamentals of analogue publishing of scarcity of content, and the role of the publisher as an intermediary par excellence according to Bhaskar is under threat. He says authors keen to 
self-publish have many choices including the Kindle Direct Publishing, and CreateSpace. Amazon has bestselling self-published authors such as Amanda Hocking, Joe Konrath and Kerry Wilkinson. He also cites the example of JK Rowling's Pottermore site which sells e-books, disintermediating publishers and authors such as Seth Godin who launched the Domino Project with the help of Amazon initially a web offering and later included print versions.

Giles Clark and Angus Philips (2014) point out that digitization transforms the value chain while simultaneously eliminating many players and processes and at the same time adding on new players and processes. They cite examples of authors disintermediating publishers, publishers bypassing wholesalers and retailers, retailers becoming publishers, librarians acting as university publishers, agents taking on the role of publishers, etc. He traces the growth of self-publishing through vanity publishing where authors bear the expenses of production but are not offered marketing support, to author service companies which offer various services for a fee while allowing the author to retain copyright. The author services companies now armed with technology-led solutions offer editing, layout, POD, digital marketing, social media presence, content discoverability techniques, and updated data analytics of sales, trends, etc.

Keith Ogorek (2018) says self-publishing has transformed the power equations in the world of publishing to authors - authors get to decide what is read as different from publishers, agents and editors deciding what is on offer to readers. He says it fosters a democratic process, and a viable alternative with better books getting published under the self-publishing system and the ideas of self-published authors being scouted by Hollywood. Elaborating on the options under self-publishing, Ogorek talks about platforms which allow authors to do everything themselves, others that provide specialised services for authors while the author coordinates activities and yet another method wherein the author solutions company provides support throughout the publishing process. He cites advantages of self-publishing over traditional publishing as authors get to retain control over content and copyright, and speed-to-market decisions, but bear the cost of production and get a higher royalty than the traditional system. Promotion and content discoverability is done both offline and online through physical distributors and online sellers and social media based on an understanding of the audience. Naveen Valsakumar (2018) says creating a minimum viable product like what "app"developers do is the goal of self-publishers. He explains the importance of technology in self-publishing and of offering tools, packages and guided publishing programmes updated frequently and customised to author needs in addition to providing data analytics and trends. Relating his experiences with self-publishing in India, he says, authors have complete control over their works - he calls author the CEO of the operation and his firm Notion Press charges authors for services and authors get 100 per cent royalty on their works. He says his firm performs traditional publishing roles of guiding authors and enabling them to bring out an industry standard book.

Nitin Shah (2018) describes the process of self-publishing as author-financed publishing with partial or full support from author-solution firms. He says some authors are skilled in their domain and sure of their content but need marketing support. Many authors seek help for cover design, ISBN, editorial and typesetting support apart from help for content discoverability and having physical copies made available at strategic retail outlets and online stores. At Sapna, which Nitin heads, authors get the benefit of physical distribution through the Sapna retail stores and through their online presence as also from book launches, book events and book fairs organised by them.

\section{OBJECTIVES}

1. To analyse the author-publisher relationships with regard to(a). Direct dealings with publishers sans agents(b). Contractual agreement with Publishers and (c). Satisfaction with royalty received.

2. To find out if Indian authors consider time delay a huge drawback in their dealings with publishers.

3. To understand from Indian authors if they have found it easy to get a publisher and if first time authors find it difficult to get published.

4. To study if Indian authors consider self-publishing a viable option.

\section{RESEARCH METHODOLOGY}

This study adopts a descriptive research design. The data source is a combination of primary and secondary sources. The research tool is a well-structured questionnaire. The period of study is between January 2018 and March 2018. The respondents to the questionnaire are authors estimated to be around 5,00,000 authors in India. The sample size is 408 respondents mostly academic, but not limited to professional and higher education authors. The sampling methodology is a mix of random, stratified random and convenience sampling from various sources including universities, colleges, professionals, social media platforms and allied networks. The data collection involved a pilot study of personal interviews with 50 authors, followed by email, and hardcopy collection of information, collection of responses from professionals, academicians, social media contacts and their networks.

\subsection{Data Interpretation and Analysis}

\section{Table 1 Author-Publisher Relationship: Interactions}

\begin{tabular}{|c|c|c|c|c|c|c|c|c|c|}
\hline $\begin{array}{l}\text { Author-publisher } \\
\text { relationship factors }\end{array}$ & Always & Often & $\begin{array}{l}\text { Some } \\
\text { times }\end{array}$ & Rarely & Never & Total & Mean & SD & $\begin{array}{c}\text { Fried } \\
\text { man } \\
\text { test }\end{array}$ \\
\hline Deal directly with publishers & $\begin{array}{c}240 \\
(58.8)\end{array}$ & $\begin{array}{c}92 \\
(22.5)\end{array}$ & \begin{tabular}{|c|}
42 \\
$(10.3)$
\end{tabular} & \begin{tabular}{|c|}
27 \\
$(6.6)$
\end{tabular} & $\begin{array}{c}7 \\
(1.7)\end{array}$ & \begin{tabular}{|c|}
408 \\
$(100.0)$
\end{tabular} & 4.30 & 1.01 & \\
\hline $\begin{array}{l}\text { Memorandum of Agreement } \\
\text { (MoA) with publisher }\end{array}$ & $\begin{array}{c}252 \\
(61.8)\end{array}$ & $\begin{array}{c}59 \\
(14.5)\end{array}$ & \begin{tabular}{|c|}
41 \\
$(10.0)$
\end{tabular} & $\begin{array}{l}26 \\
(6.4)\end{array}$ & $\begin{array}{c}30 \\
(7.4)\end{array}$ & $\begin{array}{c}408 \\
(100.0) \\
\end{array}$ & 4.16 & 1.26 & \\
\hline $\begin{array}{l}\text { Satisfied with annual royalty } \\
\text { paid by Publisher }\end{array}$ & $\begin{array}{c}110 \\
(27.0) \\
\end{array}$ & $\begin{array}{c}117 \\
(28.7) \\
\end{array}$ & \begin{tabular}{|c|}
132 \\
$(32.4)$ \\
\end{tabular} & $\begin{array}{c}28 \\
(6.9) \\
\end{array}$ & $\begin{array}{c}21 \\
(5.1) \\
\end{array}$ & \begin{tabular}{|c|}
408 \\
$(100.0)$ \\
\end{tabular} & 3.65 & 1.10 & \\
\hline $\begin{array}{l}\text { Time taken by publishers a } \\
\text { huge drawback in getting } \\
\text { published }\end{array}$ & $\begin{array}{c}64 \\
(15.7)\end{array}$ & $\begin{array}{c}109 \\
(26.7)\end{array}$ & $\begin{array}{c}145 \\
(35.5)\end{array}$ & \begin{tabular}{|c|}
68 \\
$(16.7)$
\end{tabular} & $\begin{array}{c}22 \\
(5.4)\end{array}$ & $\begin{array}{c}408 \\
(100.0)\end{array}$ & 3.30 & 1.08 & \\
\hline $\begin{array}{l}\text { First time authors find it } \\
\text { difficult to get published in } \\
\text { India }\end{array}$ & $\begin{array}{c}136 \\
(33.3)\end{array}$ & $\begin{array}{c}112 \\
(27.5)\end{array}$ & $\begin{array}{c}111 \\
(27.2)\end{array}$ & $\begin{array}{l}30 \\
(7.4)\end{array}$ & $\begin{array}{c}19 \\
(4.7)\end{array}$ & $\begin{array}{c}408 \\
(100.0)\end{array}$ & 3.77 & 1.12 & \\
\hline Ease of finding publishers & $\begin{array}{c}68 \\
(16.7)\end{array}$ & $\begin{array}{c}111 \\
(27.2)\end{array}$ & \begin{tabular}{|c|}
136 \\
$(33.3)$ \\
\end{tabular} & \begin{tabular}{|c|}
49 \\
$(12.0)$
\end{tabular} & $\begin{array}{c}44 \\
(10.8)\end{array}$ & \begin{tabular}{|c|}
408 \\
$(100.0)$ \\
\end{tabular} & 3.26 & 1.19 & \\
\hline
\end{tabular}

Of the 408 respondents, $332(81 \%)$ dealt directly with publishers. The neutrals constituting about $10 \%$ were perhaps self-publishing and the balance $9 \%$ who did not deal directly with publishers were dealing through agents or were self-publishing. 
It is interesting to note that about $76 \%$ had Memorandum of Agreements signed with publishers. The remaining did not have valid publishing agreements with authors.

About $55 \%$ of the authors were satisfied with the royalty paid by their authors while $32 \%$ were not sure whether they were getting adequate royalty or not. About $13 \%$ were clearly dissatisfied with the royalties received for their works from their publishers. The mean scores of 4.30, and 4.16 confirms that a very high percentage of authors deal directly with publishers and have signed publishing contracts. A mean score of 3.65 confirms the fact that a moderately high percentage of authors are satisfied with the royalties received from their publishers.

It is surprising that only $42 \%$ of authors consider the time taken by publishers to publish as a huge drawback. About $36 \%$ of the authors are neutral and $22 \%$ do not consider it a huge drawback. As to the question of whether first time authors find it difficult to get published in India, $60 \%$ of the respondents agreed with this, while $27 \%$ were neutral and $13 \%$ did not agree with this. A high mean score of 3.77 corroborates the fact that first time authors find it moderately difficult to get published in India. This is further substantiated by author respondents constituting $44 \%$ who found it easy to get published while $23 \%$ found it not so easy to get published and $32 \%$ were neutral. A mean score of 3.26 recognises the fact that getting published is not so easy for authors.

Table 2 Self-publishing a viable option

\begin{tabular}{|c|c|c|c|c|c|c|c|c|c|}
\hline $\begin{array}{c}\text { Author-publisher relationship } \\
\text { factors }\end{array}$ & Always & Often & $\begin{array}{c}\text { Some } \\
\text { times }\end{array}$ & Rarely & Never & Total & Mean & SD & $\begin{array}{c}\text { Fried } \\
\text { man } \\
\text { test }\end{array}$ \\
\hline Self-Publishing a viable Option & $\begin{array}{c}58 \\
(14.2)\end{array}$ & $\begin{array}{c}76 \\
(18.6)\end{array}$ & $\begin{array}{c}130 \\
(31.9)\end{array}$ & $\begin{array}{c}66 \\
(16.2)\end{array}$ & $\begin{array}{c}78 \\
(19.1)\end{array}$ & $\begin{array}{c}408 \\
(100.0)\end{array}$ & 2.92 & 1.29 & \\
\hline
\end{tabular}

It is indeed surprising that only $33 \%$ of authors in the survey considered self-publishing a viable option. About $35 \%$ considered self-publishing not a viable option and $32 \%$ were neutral. The mean score of 2.92 confirms the fact that self-publishing is not considered a viable option by a significant proportion of authors in the survey.

\section{SUMMARY OF FINDINGS}

About $81 \%$ per cent of author respondents in the survey deal directly with publishers and $76 \%$ have signed Memorandum of Agreements. About $65 \%$ are happy with the royalties received from their publishers. It is however surprising that only $42 \%$ of the respondents consider the time taken to publish as a huge drawback. About $60 \%$ felt that first time authors find it difficult to get published. It is indeed astonishing that only $33 \%$ of authors considered self-publishing a viable option.

\section{RESEARCH BASED SUGGESTIONS}

1. Disintermediation is rife and all stakeholders in the publishing domain strive to reduce costs, have direct dealings with readers/users and make use of technology to achieve content discoverability. In the process, some intermediaries like wholesalers and retailers may see dwindling business with a total disruption of established ways of doing business.

2. Publishers, especially traditional publishers will do well to cater to readers who require content that needs immersive reading. As Esposito expounded, books should not become like web pages but more like themselves.

3. Content in the digital era is prolific and suspect. Traditional publishers would do well to filter, publish selectively and publish well-researched and quality-oriented books and stand for value and scholarship.

4. Traditional publishers could adopt technology in all spheres of operation especially in marketing and aiding content discoverability and in furthering their geographical reach.

5. Just as traditional publishers can straddle both worlds of print and digital, so too can self-publishing authors perhaps create interest in their offerings through the digital route and then sign with traditional publishers for print versions.

\section{CONCLUSION}

In the digital era, disintermediation is happening in every loop and process of the publishing value chain. Likewise, self-publishing is prolific and many authors are experimenting with the democratic publish-first, filter-later process on offer in the new digital scheme of things. But as indicated by author respondents in this survey, they are wary of the viability of self-publishing especially in terms of market-reach. As such, publishers in the traditional mould should strive to further strengthen their relationships with authors, and aim for better professionalism in their efforts. In addition, they should enhance their marketing reach through digital marketing and like digital tools.

\section{REFERENCES}

1. Atreya Rasana, My Self-Publishing Journey, http:www.thehindu.com/books/my-selfpublishing-journey/article3727190 .ece, 2012

2. Bhaskar, Michael, The Content Machine, 2013, Anthem Press, London, page 43

3. Cantatore, Francina C, Negotiating a Changing Landscape: Authors, Copyright and Digital Evolution, 2010, Bond University (accessed in 2015)

4. Evans Philip B, Wurster Thomas S, Strategy and the New Economics of Information, Creating Values in the Networked Economy, 1999, Harvard Business Review, Boston

5. FICCI report, Publishers Law Book, 2013

6. Frania Hall, Digital Change and Industry Responses, 2016. Logos 27/2.

7. Frania Hall, The Business of Digital Publishing, 2013, Routledge, London.

8. Giles Clark, Angus Philips, Inside Book Publishing 5 E, 2014, Routledge, London

9. Joseph Esposito, The Multifarious Book, 2017, The Scholarly Kitchen.

10. Ogorek, Keith, Online Author Education and Support, Ed (Devasar N) Publishers on Publishing, 2018, AAP, New Delhi

11. Shah Nitin, Technology-Based Solutions, Ed (Devasar N) Publishers on Publishing, 2018, AAP, New Delhi

12. Thatipall, Mallik, I am on the Right Path, 2018, The Hindu https://www.thehindu.com/books/books-authors/savi-sharma-everyone-ha s-a-story-2-author/article25226630.ece

13. Vaara, Matias, Digital Disruption Faced by the Book Publishing Industry, 2010, Tampere University, (Accessed from the web in 2016)

14. Valsakumar, Naveen, Self-Publishing, Ed (Devasar N), Publishers on Publishing, 2018, AAP, New Delhi

15. Smith, Kevin, The Publishing Business: From p-books to e-books, 2012, Ava Books, Switzerland

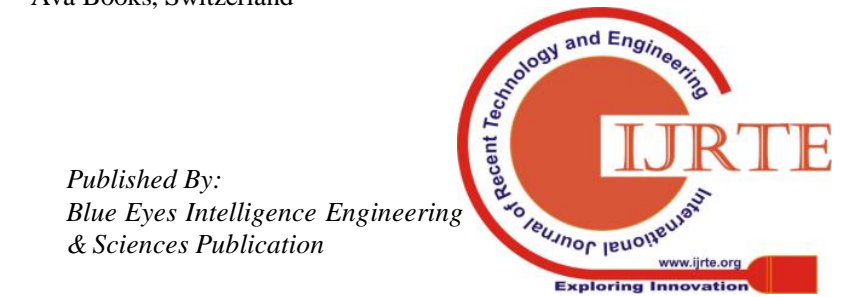

